\title{
THE EFFECT OF PARA-INFLUENZA TYPE 1 (SENDAI) VIRUS INFECTION ON EARLY PREGNANCY IN THE RAT
}

\author{
G. R. COID* AND G. WARDMAN \\ Clinical Research Centre Laboratories, National Institute for Medical Research, Mill Hill, \\ London, N.W.7
}

(Received 3rd February 1970)

\begin{abstract}
Summary. Infection of rats, 4 to 5 days pregnant, with aerosols of Sendai virus induced resorption of all embryos in nine out of the twelve animals examined.

Virus was recovered from the conceptus of only one of fourteen additional rats, although each was shown to have the agent in the lungs.

It is concluded that the observed termination of pregnancy is not due to virus growth within the cells of the conceptus, but is likely to be caused indirectly by the systemic upset in the pregnant animal induced by the respiratory disease.
\end{abstract}

\section{INTRODUCTION}

Some retrospective studies on influenza virus infection in pregnant women have indicated the possibility of its association with an increased incidence of foetal anomalies, abortion and stillbirths, particularly when infections occur early in pregnancy (Harris, 1919; Bland, 1919; Coffey \& Jessop, 1959; Pleydell, 1960; Saxén, Hjelt, Sjöstedt, Hakosalo \& Hakosalo, 1960; Hardy, Azarowicz, Mannini, Medearis \& Cooke, 1961; Roszkowski \& Kietlinska, 1964). Other observations conclude that influenza has no effect on the foetus or on the outcome of pregnancy (Gampbell, 1953; Walker \& McKee, 1959; Wilson, Heinz, Imagawa \& Adams, 1959; Hewitt, 1962).

In view of these varied conclusions, it seemed that to study the problem in a suitable animal species with a virus closely related to influenza could provide a useful model for investigating the effect of viral respiratory disease on the developing embryo.

The present experiments in rats were designed to study the effect of respiratory virus disease on the fertilized ovum about the time of implantation. The equivalent stage of pregnancy cannot usually be detected in women.

* Present address: The Clinical Research Centre, Harrow HAl 3UJ, Middlesex. 


\section{MATERIALS AND METHODS}

Rats

Time-mated, Sprague-Dawley rats, 4 to 5 days pregnant, were obtained from the breeding colony of the National Institute for Medical Research, Mill Hill, London. The day on which the vaginal plug was found was considered as Day 0 of pregnancy. During the experiments they were held separately in plastic cages. Unrestricted access to food and water was provided. At the end of each experiment, none of which lasted more than 7 days, the animals were killed either by an overdose of chloroform or ether, or, where virus isolations were attempted, by a lethal dose of pentobarbitone sodium administered intraperitoneally.

\section{Virus}

The virus used was a strain of Para-influenza type 1 (Sendai) originally recovered from mice and subsequently shown to produce respiratory disease in young rats (Tyrrell \& Coid, 1970). It was propagated in the allantoic cavity of 10-day embryonated eggs and the fluid harvested after incubation for 3 days at $33^{\circ} \mathrm{C}$ and tested for haemagglutinating activity using $0.5 \%$ washed chick erythrocytes. The number of egg-infectious doses in the suspension was estimated to be $5 \times 10^{8} / \mathrm{ml}$. Killed virus was prepared by heating the suspension in a water bath at $56^{\circ} \mathrm{G}$ for $1 \mathrm{hr}$.

\section{Administration of virus to rats}

The rats were held in small wire mesh cages and placed in a specially adapted stainless steel isolation cabinet of approximately 200 litre capacity and exposed to an aerosol of virus generated by a Collison spray (Microbiological Research Establishment, Porton) from $8.0 \mathrm{ml}$ of suspension. After $45 \mathrm{~min}$, they were removed from the cabinet to an isolation room. This procedure was also adopted for the administration of the same amount of dead virus to seven control rats and for the administration of normal allantoic fluid to one other. Three control animals received no treatment.

\section{Examination of tissues for virus}

In the experiments designed to obtain tissues for virological examination, the samples were removed aseptically immediately after killing the rats and stored at $-70^{\circ} \mathrm{C}$ until required for attempted virus isolation in embryonated eggs. Samples taken consisted of cardiac blood, conceptus and implantation sites in the uterus, lung, liver and spleen.

For injection into the allantoic cavity of eggs, the blood samples were made into a suspension by grinding the clot in an equal volume of Eagle's balanced salt solution. At least three eggs were injected with $0.2 \mathrm{ml}$ of each sample. Other tissues were also prepared for injection in $0 \cdot 2-\mathrm{ml}$ amounts by grinding approximately $0.4 \mathrm{~g}$ in $1.6 \mathrm{ml}$ of Eagle's solution. After incubation of the eggs for 3 days at $33^{\circ} \mathrm{C}, 0 \cdot 2-\mathrm{ml}$ samples of allantoic fluid were examined for the presence of haemagglutinating activity.

The assay of the blood serum for antibodies to the virus was carried out by standard procedures for haemagglutination-inhibition antibody $(\mathrm{HI})$ tests. 
Tissues for histological examination

Each uterus was preserved in $10 \%$ formol saline and transverse serial sections through the centre of implantation sites were prepared and stained with haematoxylin and eosin.

\section{RESULTS}

Effest of virus respiratory disease on embryos

Three days after infection with live virus, the rats usually showed signs of diminished activity, staring coat and loss of appetite. Obvious signs of respiratory distress developed between 5 and 7 days after exposure; some animals were more severely affected than others. Infected animals invariably lost weight during the experiments, while all non-infected control animals remained in good health and gained weight.

In the groups given live virus (Table 1), the embryonic development from three animals appeared on macroscopic examination to have reached the same

TABle 1

THE EFFECT OF SENDAI VIRUS RESPIRATORY DISEASE ON EMBRYONIG DEVELOPMENT IN RATS INFECTED BETWEEN THE 4TH AND 5TH DAYS OF PREGNANCY

\begin{tabular}{c|c|c|c}
\hline \multirow{2}{*}{ Exp. no. } & $\begin{array}{c}\text { Time after } \\
\text { infection } \\
\text { (days) }\end{array}$ & $\begin{array}{c}\text { No. of rats showing } \\
\text { resorption of all } \\
\text { embryos }\end{array}$ & $\begin{array}{c}\text { Total no. in each } \\
\text { group }\end{array}$ \\
\cline { 2 - 3 } & & Infected & $\begin{array}{c}\text { Controls } \\
\text { (non-infected) }\end{array}$ \\
\hline 1 & 5 & $2 / 2$ & $0 / 2$ \\
2 & 5 & $1 / 2$ & $0 / 3$ \\
3 & 7 & $1 / 2$ & $0 / 2$ \\
4 & 7 & $2 / 3$ & $0 / 1$ \\
5 & 7 & $2 / 2$ & $0 / 3$ \\
6 & 7 & $1 / 1$ & $0 / 1$ \\
\hline Total: all experiments & $9 / 12$ & $0 / 12$ \\
\hline
\end{tabular}

stage as the embryos from the control group. However, in each of the remaining nine animals, there was marked evidence of retarded embryonic development at all implantation sites, which were much smaller, darkly haemorrhagic, and less circumscribed compared with the controls. Occasionally, a discharge of dark blood was seen in the vagina.

Evidence of the impaired embryonic development was obtained by comparing the microscopic appearance of sections taken through the middle of implantation sites from control and infected animals.

Plate 1, Figs. 1 and 2 show sections from control animals 9 to 10 and 11 to 12 days pregnant, respectively, and Pl. 1, Figs. 3 and 4 are from sections of infected animals at comparable stages. It can be seen that, while normal embryonic development is present in the controls, the infected animals show resorption 
manifested by a breakdown of the decidua and apparent absence of discrete embryonic development.

\section{Isolation of virus}

To investigate the possibility that the virus might exert a direct effect on the developing embryo, material was taken from each of three animals infected 7 days previously with live virus. Samples of the conceptus and uterus were examined for the presence of virus. None was found in any animal. HI antibody was present at a titre of $1: 40$ in one and $1: 80$ in the other two animals.

In view of these findings, it was considered possible that the presence of circulating antibody might have neutralized the virus in the blood, prevented its

TABle 2

ISOLATION OF SENDAI VIRUS FROM TISSUES OF PREGNANT RATS FOLLOWING RESPIRATORY INFECTION INDUCED 4 TO 5 DAYS POST COITUM

\begin{tabular}{c|c|c|c|c|c|c}
\hline \multirow{2}{*}{$\begin{array}{c}\text { Time after } \\
\text { infection } \\
\text { (days) }\end{array}$} & \multicolumn{4}{|c|}{ No. of isolations/No. of tissues examined } & \multicolumn{1}{c}{$\begin{array}{c}\text { Serum } H I \\
\text { antibody titre }\end{array}$} \\
\cline { 2 - 6 } & Blood & Lungs & $\begin{array}{c}\text { Uterus } \\
\text { and } \\
\text { conceptus }\end{array}$ & Liver & Spleen & \\
\hline 3 & $0 / 9$ & $9 / 9$ & $1 / 9$ & $3 / 9$ & $0 / 9$ & All $<1: 5$ \\
$4 \frac{1}{2}$ & $0 / 5$ & $5 / 5$ & $0 / 5$ & $0 / 5$ & $0 / 5$ & $\begin{array}{c}\text { All }<1: 5 \\
: 40,1: 80, \\
1: 80\end{array}$ \\
\hline
\end{tabular}

spread from the lungs, and inhibited its isolation from the embryonic tissues. Gonsequently, experiments were designed in which attempts were made to isolate the virus before antibody developed. In addition, to determine if the virus was likely to propagate preferentially in embryonic tissue, samples of liver and spleen were examined for comparison. However, as shown in Table 2, even though the lungs of all animals examined contained virus 3 and $4 \frac{1}{2}$ days after infection, it was recovered from the uterus and conceptus of only one animal and from the liver of three. In no instance was virus detected in blood or spleen from the pregnant animals.

\section{DISCUSSION}

The results show that when a dose of Sendai virus sufficient to cause severe respiratory disease is given to pregnant rats during the time of implantation of the ovum, in the majority of animals all the embryos undergo resorption. That this is produced by an indirect effect of the agent on the conceptus is suggested by the results of the attempted virus isolation. Thus, the virus was present in the conceptus of only one of fourteen animals examined at 3 or $4 \frac{1}{2}$ days after infection, even though there was no evidence of circulating antibody which could neutralize the virus. This finding may not be surprising since virus could not be demonstrated in the blood or spleen and only occasionally in liver, indicating that the infection does not spread readily from the lungs to other tissues. 


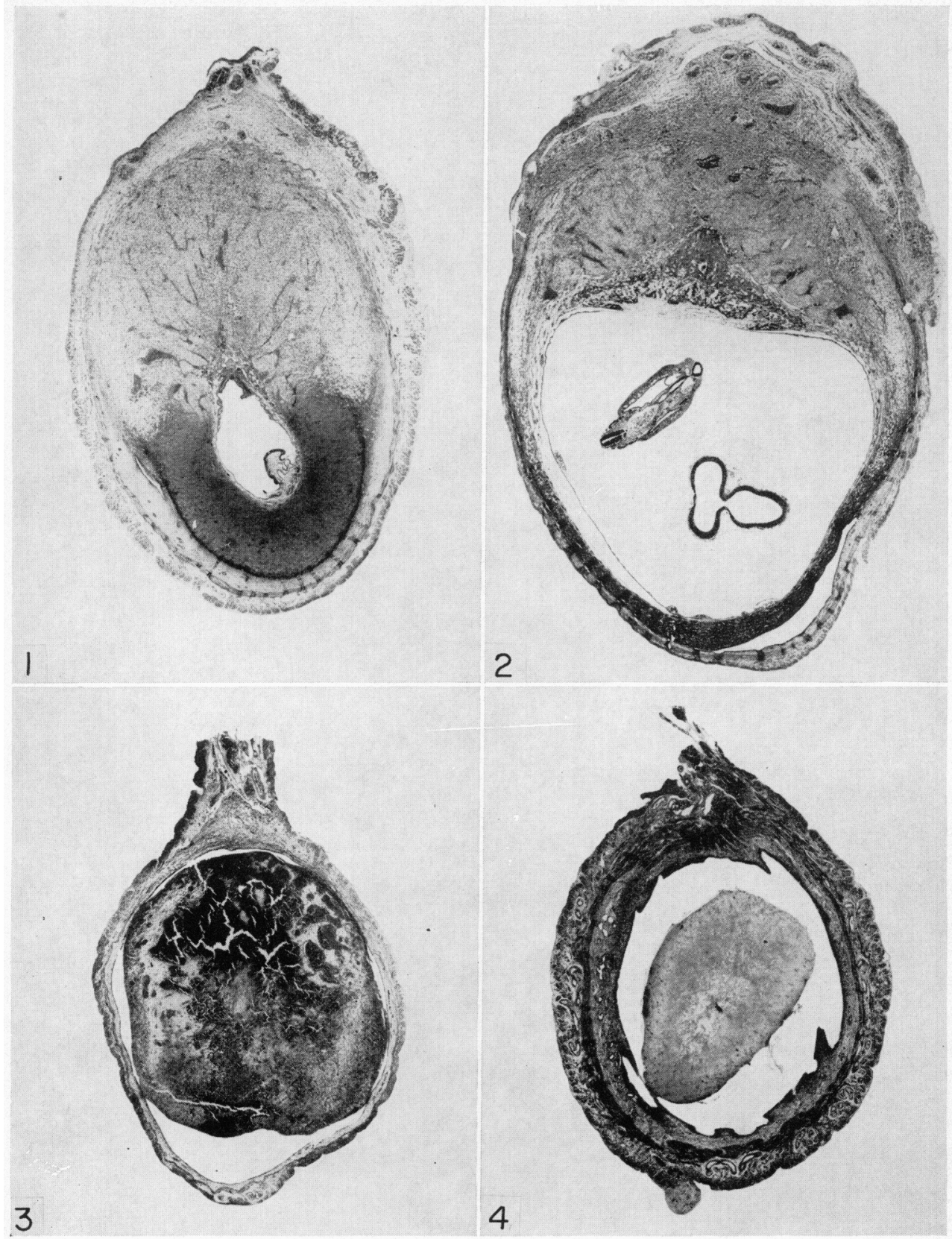

Figs. 1 and 2. Transverse sections through the centre of implantation sites from control rats, showing normal embryonic development; Fig. 1,9 to 10 days pregnant; Fig. 2, 11 to 12 days pregnant. $\mathrm{H} \& \mathrm{E}, \times 14.5$.

FIGS, 3 and 4 . Transverse sections through the centre of implantation sites from Sendaiinfected rats, showing resorption of conceptus; Fig. 3, 9 to 10 days pregnant; Fig. 4, 11 to 12 days pregnant. $\mathrm{H} \& \mathrm{E}, \times 14 \cdot 5$.

(Facing p. 42) 
It is recognized that pregnancy termination either by resorption or prevention of implantation can be induced in rodents following severe systemic upset produced by various methods, especially when this occurs during the first trimester of pregnancy. For example, Barry (1920) reports a significantly lower pregnancy rate in rats which were underfed from the day of copulation as compared with the rate in animals underfed from Day 11 after mating. Furthermore, Hsu (1948) showed that pregnancy termination was significantly increased in rats subjected to heat-treatment, particularly when such treatment was applied before, during or immediately after implantation. These times correspond approximately to the periods when the rats in the present experiments began to show clinical signs of disease. Thus, the resorptions observed in our investigations may represent a similar response to some as yet unidentified factor involved in the general systemic distress of the mother during the acute stages of the respiratory disease.

\section{ACKNOWLEDGMENT}

We are grateful to Miss P. M. Furr for technical assistance.

\section{REFERENCES}

BARRY, L. W. (1920) The effects of inanition in the pregnant albino rat, with special reference to the changes in the relative weights of the various parts, systems, and organs of the offspring. Contr. Embryol. 11, 91.

BLAND, P. B. (1919) Influenza in its relation to pregnancy and labor. Am. F. Obstet. Gynec. 79, 184.

CAMPBeLL, W. A. B. (1953) Influenza in early pregnancy; effects on the foetus. Lancet, i, 173.

Coffey, V. P. \& Jessop, W. J. E. (1959) Maternal influenza and congenital deformities; a prospective study. Lancet, ii, 935.

Hardy, J. M. B., Azarowicz, E. N., Mannini, A., Medearis, D. N. \& Cooke, R. E. (1961) The effects of Asian influenza on the outcome of pregnancy, Baltimore, 1957-1958. Am. F. publ. Hlth, 51, 1182.

HARRIs, J. W. (1919) Influenza occurring in pregnant women; a statistical study of thirteen hundred and fifty cases. F. Am. med. Ass. 72, 978.

HewtT, D. (1962) A study of temporal variations in the risk of fetal malformation and death. Am. $\mathcal{J}$. publ. Hlth, 52, 1676.

Hsv, C. Y. (1948) Influence of temperature on development of rat embryos. Anat. Rec. 100, 79.

PLeYdell, M. J. (1960) Anencephaly and other congenital abnormalities; an epidemiological study in Northamptonshire. Br. med. F. i, 309.

Roszxowski, I. \& KIETLINSKA, Z. (1964) Etiology of congenital malformations in the newborn. Obstet. Gynec., N.r. 23, 893.

Saxen, L., Hjelt, L., Sjöstedt, J. E., Hakosalo, J. \& Hakosalo, H. (1960) Asian influenza during pregnancy and congenital malformations. Acta path. microbiol. scand. 49, 114.

TYrReLL, D. A. J. \& Com, C. R. (1970) Sendai virus infection of rats as a convenient model of acute respiratory infection. Vet. Rec. 86, 164.

Walker, W. M. \& McKeE, A. P. (1959) Asian influenza in pregnancy; relationship to fetal anomalies. Obstet. Gynec., N.Y. 14, 394.

Wilson, M. G., Heinz, H. L., Imagawa, D. T. \& Adams, J. M. (1959) Teratogenic effects of Asian influenza. F. Am. med. Ass. 171, 638. 